\title{
Рибалка Ірина Сергіївна,
}

доцент кафедри експлуатації суднових енергетичних установок

Азовського морського інституту Національного університету

«Одеська морська академія», м. Маріуполь, Україна,

кандидат філологічних наук

ORCID iD 0000-0001-6648-7219

iryna190781@ukr.net

\section{ЧОЛОВІЧІ ОБРАЗИ У ОПОВІДАННЯХ Б. ЕРСКІН}

У статті здійснено аналіз чоловічих образів у творах відомої британської письменниці Б. Ерскін, які досі не перекладені українською мовою. Зроблено спробу застосувати гендерні прийоми для вивчення суто літературознавчих проблем. Послуговуючись класифікачією соціальних чоловічих моделей поведінки Н. Жаданової, ми проаналізували збірку оповідань «Несподівані зустрічі» та виявили шість типів чоловічих образів: «Личар-аристократ», «Джентльмен», «Товариш», «Романтик», «Син», «Батько», які не є позитивними або негативними. Вони завжди комбінують чі риси, що додає останнім реалістичності та додатково характеризує головну героїню. Так, образ типу "Джентльмен» найчастіше зустрічається у вище названій збіриі, що може пояснюватися національними та культурними традиціями суспільства, яке описане у оповіданнях. Вектор вибраного дослідження є перспективним у напрямі міждисциплінарних досліджень, що останнім часом отримали широке поширення у гуманітарній науковій практиці.

Ключові слова: гендер, тип образу.

Барбара Ерскін є однією з відомих представниць сучасної жіночої британської літератури. Вона автор тринадцяти романів і трьох збірок оповідань, які демонструють інтерес письменниці до історії як до чогось надприродного. Ї̈і всесвітньовідомий бестселер "Lady of Нау" («Леді із сіна» (1986). Тут і далі переклад автора. - I. Р.) був перекладений на десятки мов і проданий у кількості понад мільйон копій по всьому світу. Далі була збірка оповідань "Encounter" («Несподівана зустріч» (1990). Пер. наш. - I. Р.), яка теж отримала широке визнання.

Актуальність нашого дослідження зумовлена загальним інтересом до вивчення проблем гендеру в сучасній гуманітарній науці. Представлена робота має певний новаторський характер: $з$ одного боку, аналіз художнього твору здійснюється з урахуванням деяких засад гендерних досліджень у комбінації з суто літературознавчими методами, а з другого, матеріалом для аналізу стали ті твори Б. Ерскін, які досі не перекладені ні російською, ні українською мовами. Метою роботи $є$ дослідити типи чоловічих образів у творах Б. Ерскін, що увійшли у збірку «Несподівана зустріч». Для досягнення цієї мети було проаналізовано текст, що складає майже 26 друкованих аркушів.
Як ми вже зазначали раніше, творчість Б. Ерскін не $є$ добре вивченою та дослідженою ані в україномовному чи російськомовному літературознавстві, ані західними фахівцями. Однак читачки на форумах, де обговорюються твори письменниці, зазначають, що однією з найбільш відмінних рис їі романів $є$ те, що надприродні сили завжди приходять через сни та бачення і безпосередньо впливають на долю головного героя. Причому останній спочатку 3 усіх сил намагається відганяти їх, проте зрештою починає вірити і завдяки цьому кардинально змінює своє ставлення до власного життя та оточення. Б. Ерскін віртуозно використовує цю ідею, щоб зробити свої твори більш захоплюючими, реалістичнішими і виразнішими. Читачки стверджують, що саме цього вони і чекають від ії романів.

Однак не всі твори авторки присвячені потойбічному світу, тобто привидам, прокляттям, спокутуванню гріхів та іншому. У письменниці є оповідання, які чимось нагадують твори О'Генрі - добрі, сповненні надії на щасливе майбутнє та віри в те, що на добрі вчинки буде добра відповідь. Цікавим $є$ той факт, що головними персонажами цих оповідань (найчастіше 3 реалістичним сюжетом) є жінки з певним життєвим досвідом: їм уже далеко за двадцять 
років, вони мають негативний досвід стосунків iз чоловіками, однак, у декого з них вистачає сил змінити щось у власному життя, а в дехто після кількох спроб все-таки не спромігся на рішучі зміни у своєму житті.

Збірка «Несподівані зустрічі», яку побачив світ у 1990 р., вміщує 44 оповідання. $Є$ там і твори написані у форматі улюбленого міксу жанрів авторки - любовно-містичний 3 елементами трилера зі щасливою розв'язкою. Однак є і добрі реалістичні замальовки з дещо повчальним кінцем, які запевнюють нас у тому, що все, що відбувається у нашому житті, має свою мету і їi лише треба побачити.

Сфера сюжетних інтересів письменниці є досить широкою та різноманітною - від історично-містичних до цілком реалістичних. Проте в одному письменниця завжди вірна собі: іii цікавлять стосунки між чоловіком і жінкою дружні, романтичні, ворожі, подружні та просто між закоханими. До речі, ці питання являють коло інтересів усіх письменниць як минулого, так і сучасного.

Так, у збірку увійшли оповідання, присвячені різним життєвим ситуаціям, побаченим очима жінки. У деяких творах оповідь ведеться від 3 особи ("A Step out of Time", "Visitors", "The Consolation Prize", "The Indian Summer of Mary McQueen”, “Excavations” («Крок із часу», «Візитери», «Розважальний приз», «Бабине літо Мері Мак-Квін», «Розкопки»), інші ж тексти написані від першої особи ("Such a Silly Thing”, "All This Childish Nonsense", "A Strange with No Name” («Якась нісенітниця», «Дитячі забавки», «Незнайомець» (пер. наш. - I. P.)).

Основним критерієм для виділення типів образів $€$ модель поведінки щодо головних жіночих персонажів. Так, згідно з класифікацією, запропонованою Н. Жадановою у роботі «Мужские образы в современной западной культуре», в якій автор аналізує соціальні моделі поведінки чоловіків, ми виявили шість типів чоловічих образів.

1. Дворянин - аристократ та лицар, який у своїх діях керується принципами громадянської честі, демонструє повагу до жіночих персонажів, опікується слабкими, сиротами та вдовими, поважає «прекрасну даму». Проте для нього можливе лише позашлюбне кохання, бо одружується він лише переслідуючи політичні інтереси та підкорюючись соціальним вимогам $[1,20]$. Такий тип маскулінного образу присутній лише у чотирьох оповіданнях збірки.

2. Джентльмен - відважний, щедрий, впевнений у собі. Він вважає себе незалежним та освіченим, але здебільшого його поведінка визначається етикетом. На відміну від Лицаря, він однаково ввічливо поводиться 3 людьми різного походження. Джентльмен завжди готовий прийти на допомогу представницям протилежної статі. Однак у жінці він бачить лише вигідну партію $[1,20]$.

3. Товариш - основні його риси - це близькість до головної героїні. Він бере активну участь у ії житті. Цей тип відрізняється від двох попередніх відсутністю суспільних настанов він завжди поряд з нею, навіть якщо оточуючі вважають такі дії неправильними. Товариш таємно закоханий у героїню, вона про це здогадується, але кохає іншого, а його використовує у власних цілях. Може бути й інший варіант: вони домовилися, що героїня дозволяє йому бути біля себе і виконувати все те, що має роботи ії чоловік, однак ніяких сексуальних стосунків не повинно бути, бо для цього у неї $є$ інший $[1,20]$.

4. Романтик - такий тип чоловічого образу не можна назвати ні позитивним ні негативним, бо він у собі їх об’єднує. Так, Романтик здатний «дістати зірку з неба» для своєї коханої, однак коли справа доходить до того, щоб заробити гроші на вечерю у гарному дорогому ресторані, він приховає свою неспроможність за несправедливим суспільством. Відмінною рисою такого типу є його нездатність вирішувати побутові проблеми самостійно.

5. Сuн - цей тип дозволяє головній героїні опікуватися собою, ніби поступаючись іï бажанню: це не він потребує піклування, а вона хоче ним опікуватися. Життя головної героїні іде паралельно з життям сина і в деяких випадках, коли це потрібно саме йому, їхні життєві лінії перетинаються. Героїня дарує йому комфортне життя, а він дозволяє любите себе, перебуваючи тим часом у пошуках себе, бо не всі оточуючі в змозі оцінити його таланти $[1,21]$.

6. Батько - проявляє свою опіку над головною героїнею у всіх сферах їі життя. Можливими є два протилежні варіанти такого типу Добрий батько та Батько-тиран. Перший тип дає змогу героїні розвиватися та допомагає досягнути своєї мети. Батько-тиран є вищим за своїм соціальним становищем, він бажає підкреслювати власну позицію на фоні своєї жінки. Він усіляко заважає їй розвиватися, забороняє займатися будь-чим, окрім того, що йому до вподоби. Аби компенсувати таке ставлення до головної героїні, Батько-тиран виконує будь-яку їі забаганку, якщо це збігається з його намірами та підкреслює його статус.

Зауважимо, що жоден з наведених вище типів образу не є суто негативним чи позитивним, що певної мірою відображає дійсну реальність у суспільстві. 
Пропонуємо зупинитися на кількох образах. Так, яскравим прикладом типу «Джентльмен» $\epsilon$ головний герой оповідання "A Step out of Time" («Крок із часу») - Роберт [2, 1-23]. У творі йдеться про сімейну пару, яка щойно одружилася і шукає собі дім. Головними персонажами оповідання $є$ Вікторія та ії̈ чоловік Роберт, який брав участь Другій світовій війні. Вони обоє $є$ вихідцями із заможних аристократичних сімей. Роберт опікується своєю дружиною, що добре видно $з$ його поведінки, й не хоче визнавати, що йому потрібна від неї допомога (поранена нога на війні досі болить): «Роберт підморгнув Вікторії, перш ніж почав вилазити з мамини, йому було важко. Вона зробила вигляд, що зайнята ручкою дверият, бо не хотіла на це дивитись, - ï̈ допомога образила б його» (пер. наш. - I. P.) $[2,1]$.

Про їхн матеріальне становище ми дізнаємося 3 думок агента 3 продажу нерухомості: «Статки иих людей незрозумілі, але ие не означає, що вони не були заможними. 〈.... Громі, особливо старі гроші, не завжди ие засвідчують. Лише нові грочі, можуть ие довести. Ці люди можуть дозволити собі ией будинок» "Статки иих людей незрозумілі, але це не означає, щзо вони не були заможними. 〈...〉. Гроші, особливо старі громі, не завжди це засвідчували. Саме нові гроші подобалося їм демонструвати. Ці люди могли дозволити собі будинок» (пер. наш. - I. Р.) $[2,3]$.

Головний герой добре вихований, він добре знає, як людина його рангу має поводитися. Як джентльмен, Роберт завжди готовий прийти на допомогу своїй дружині. Однак у жінці він бачить лише вигідну партію й слабку істоту, яку потрібно оберігати. Її бажання - це здебільшого лише забаганки, тому виконувати їх варто лише тоді, коли вони збігаються з його власними: « - Не торкайся їх! - раптом злякалася Вікторія. - Не торкайся їх, будь ласка. Ходімо. Тут мені теж не подобається. Вона відчула страх та відчай. Здавалося, вони були скрізь у иій кімнаті. - Не будь дурепою. Ми маємо побачити все ие тепер, коли ми вже тут. Подивись, сходи ведуть туди. - Нi, Роберте. Будь ласка. Паніка охопила їі. - Не йди туди. Hi... - Вікторіє! - здивовано почав він. - ВCE ДОБРЕ. Повертайся. Вона підняла руку, ніби хотіла зупинити його, але він уже незграбно підіймався крутими сходами» (пер. наш. - I. Р.) $[2,6]$.

Як вже зазначалося, для «Джентльмена» не припустимо демонструвати пристрасть чи ревнощі, бо зміна настрою чи прояв почуттів це не гідно: " - Хто то був? Хлопець, якого ти любила? Мабуть, він був молодший за мене та не каліка? Ти закохала його?» ‘...> Він похитав головою і спробував посміхнутися. - Hi. Ви йдіть. Що б ие не було, Вікторіє, ти маєш зробити ие сама» (пер. наш. - I. Р.) [2, 17]. Наведені вище приклади цілком відповідають схемі образу «Джентльмен», яку розробили I. Кон, А. Баркова, Н. Жаданова.

Персонажів цього типу ми знаходимо ще у 15 оповіданнях: "Metamorphosis", "Summer Treachery", "All You Need to Do Is Smile", "The Bath - a Summer Ghost Story", "Encounters", "Destiny", "A promise of love", "Flowers shouldn't make you cry", "Someone to Dream About", "Milestones", "Salesmanship!", “The heart will understand", "A strange with no name", "A Love Story", "A Window of the World" («Метаморфоза», «Зрадник», «Все, що потрібно, - це посмішка», «Лазня, або Літнє оповідання про привида», «Несподівані зустрічі», «Доля», «Обіцянка любові», «Квіти не мають плакати», «Про кого мріяти», «Віхи», «Управління!», «Серце зрозуміє», «Незнайомець», «Любовна історія», «Вікно у світу» (пер. наш. - I. P.)).

Найбільш типовий образ «Романтика», на нашу думку, маємо в оповіданні “The Valentine's Day Plot” («Оповідання про Валентинів день» (пер. наш. - I. P.)) [2, 73-77]. Цей твір дещо виділяється на фоні інших текстів у збірці, оскільки оповідь у ньому ведеться від особи чоловічої статі. До речі, інших головних героїв тут немає. Тож мова іде від першої особи - Девіда. Він купує квіти та улюблені парфуми для коханої жінки до дня Святого Валентина: «Звичайно, ие мав бути букет квітів до Дня Святого Валентина. Я добирав їх ретельно, по одній. Ціною не менш ніж 50 иеентів за квітку. Їй завжди подобалися рожеві, такі я й вибирав. ‘... Коли я закінчив, результат, маю визнати, мені сподобався» (пер. наш. - I. Р.) [2, 73]. Ці рядки свідчать про дуже ніжне ставлення героя до жінки: звичайний букет він добирає з особливою ретельністю. Далі Девід розмірковує, як же відправити подарунки: «Я знав, що з доставкою квітів будуть проблеми і до сніданку ще не вирішив, як саме ие зробити» «Я знав, щзо доставка квітів буде проблемою, $і$ все ще не вирішив за сніданком, як це зробити напевно» (пер. наш. I. P.) $[2,73]$. Коли жінка одержала квіти, то одразу здогадалася від кого вони й зателефонувала Девідові в офіс. Головний герой вдає ніби не відправляв ніяких квітів, бо, на його думку, це має додати ще більше романтичної загадковості. Однак жінка зізнається, що один із хлопчиків, який приніс подарунки, $є$ її син. Під час розмови з'ясовується, що у героїні є чоловік, він дуже ревний. I зараз він їде до Девіда. Якимось чином ревнивець потрапляє в офіс героя: «Я не 
знаю, як він пройшов повз мого секретаря. Він довго стояв перед моїм столом, потім посміхнувся. "Жодний інший чоловік не завалював мою дружину квітами”. ‘... . Він вийняв з кишені револьвер і натиснув на гачок. Він навіть не дав мені нічого пояснити» "Я не знаю, як він прослизнув повз мого секретаря, але він прийшов досить несподівано. Він довго стояв перед моїм столом, потім посміхнувся. - Жоден чоловік не зваблював мою дружину квітами. ‘...〉 Він вийняв з кишені револьвер і натиснув на гачок. Він навіть не дав мені нічого пояснити» (пер. наш. - I. P.) $[2,76]$.

Слід зазначити, що ім'я жінки, до якої залицявся Девід, так і залишається невідоме. Проте це і не дуже важливо, адже для героя, як з'ясовується у кінці оповідання, важливим був не результат, а сам процес флірту, що традиційно для «Романтика». Трагічна смерть героя і його останні слова приголомшують. Він упевнений, що його загибель стане відплатою тій, яка не оцінила його кохання, і тому, хто не захотів відмовитися від дружини заради ії щастя: «Та зрештою я виграв: тепер я переслідую ї обох» (пер. наш. - I. P.) [2, 77].

Зазначимо, що образи такого типу знаходимо ще в 10 оповіданнях: "Cabbage a la carte", "Filene Express", "A Private Ceremony", "The Magic of Make Believe", "A Face in the Crowd", "The Magic Carpet", "Spaces", "A Quest for Identity", "All this Childish Nonsense", "A Promise of Love" («Kaпуста a la carte», "Філіне Експрес», «Приватна церемонія», «Чари віри», «Обличчя у натовпі», «Чарівний килим», «Простір», «Питання для розуміння», «Дитячі забавки», «Обіцянка любові» (пер. наш. - I. Р.)).

Наступним за вживаністю $є$ тип «Син». Персонажів цього образу знаходимо в 6 оповіданнях. Яскравим прикладом є герой оповідання "Visitors” («Візитери» (пер. наш. - I. Р.)). Головна героїня Пен три року тому розлучилася зі своїм коханим Джо. На іiі думку, він був безвідповідальним і це заважало їхньому щастю. Пен усіляко намагалася змінити хлопця: вона пояснювала Джо його помилки, вчила правильно поводитися. Та врешті хлопець пішов від неї до молодшої. Про всі ці подробиці спільного життя ми дізнаємося з розмови колишніх закоханих, яка сталася через три роки після розриву.

Оповідь починається з того, що одного вечоpa, напередодні Різдва, яке Пен вже змирилася 3 тим, що проведе наодинці зі своїми думками та спогадами, їй зателефонував Джо. Він попросив дозволу зустріти це свято разом з нею, бо йому було самотньо. Приїхавши до Пен, Джо зізнається, що не сам. Звісно, це бентежить жін- ку, яка упевнена, що він приїхав разом зі своєю дівчиною. Та вона вже не може відмовити. Джо йде до машини й повертається 3 кошиком у руках. У ньому спить його син, від якого відмовилася власна мати. Джо розповідає Пен, що оформив всі належні документи і дитина тепер його, тому він має доглядати сина. Пен не може вимовити ані слова від здивування. Вночі Джо будить головну героїню та пропонує їй стати матір'ю для його сина. Адже він усвідомив, що в неї вистачить і сили, і розуму жити 3 ними двома.

Як уже зрозуміло з сюжету оповідання, характер Джо не є цілком негативним та й сам образу «Син» подібний. Такий типаж вимагає від головної героїні сміливості брати на себе відповідальність та підтримувати «Сина» в усіх його вчинках.

Доказом того, що персонаж Джо належить до типу «Син», є образ самої головної героїні: «Тож три роки і кілька справ, які підвищують моральний дух, можуть багато зробити для прийняття таких рішень. У будь-якому разі мені було иікаво. Що ж сталося із моїм Джо за иі три роки? Я поклала пару полінець у камін i налила собі випити» (пер. наш. - I. Р.) [2, 23]. Так, чекаючи доки Джо повернеться від машини $з$ кимось, Пен дуже не хотіла бачить IIÏ. Однак, як би там не було, вона не змогла йому відмовити: «Яке мені діло до того, скільки жінок він привіз. Без сумніву, він прийшов за мойм схваленням, перш ніж освідчитися тій, яка зрештою виявилася настільки дурною, щоб сказати “так”. Це була найбезглуздіша річ, яку Джо міг би зробити. ‘...〉. Хто б вона не була, вона була сукою» (пер. наш. - I. Р.) [2, 24].

Слід укотре наголосити на тому, що образ Джо не є негативним. Адже він піклується про дитину й не тікає від своїх батьківських обов'язків, але він не впевнений у тому, чи зможе самотужки виховати сина: «Я маю знайти кого-небудь, щзоб доглядав за ним» (пер. наш. I. P.) $[2,25]$. Джо намагається якось залагодити свою провину перед Пен. Проте він це робить так, ніби маленький бешкетник, який знає, що накоїв шкоду: "Мені подобається твоє довге волосся. Ти виглядаєш казково; дійсно гарно», «Ніхто з моїх жінок не готував так, як ти» (пер. наш. - I. Р.) [2, 24].

Зрештою головна героїня доходить висновку про те, що саме ії поведінка та спосіб життя спонукали Джо повернутися до неї, коли у нього на руках опинилася маленька дитина: «Я не відчула ні помилки у власних ревнощах, ні розчарування, коли він ие говорив; лише така дурепа, як я, дбала б про такого чоловіка, як він» (пер. наш. - I. Р.) [2, 30]. Як уже зазначалося, 
хлопець розірвав їхні стосунки через бажання Пен усе контролювати. Проте коли Джо опинився перед вибором, чи віддавати дитину в притулок, чи виховувати самому, то вирішив, що саме ця жінка зможе йому допомогти. 3 одного боку, вчинок справжнього чоловіка, з другого - бажання перекласти відповідальність на когось іншого.

Ще одним персонажем, якому слід приділити увагу, є образ чоловіка Мері, головної героїні оповідання "The Indian Summer of Mary McQueen” («Бабине літо Мері Мак-Квін») [2, 213-240]. Цей твір є неординарним, бо лише у кінці ми бачимо Його. Про все, що відбувається, ми дізнаємося 3 думок та спогадів самої героїні. Мері прожила у шлюбі зі своїм чоловіком понад двадцять років, а потім він її покинув заради молодої коханки. Звісно, Мері була у розпачі певний час. Однак згодом вона згадала про захоплення своєї молодості - малювання - й почала знову ним займатися. Ïі життя наповнилося сенсом: вона робила лише те, що приносило їй задоволення: вдягалася у зручний для себе одяг, носила зручні туфлі й не витрачала багато часу на зачіску. Малюнки та картини Мері бачили іiі знайомі. Твори жінки їм подобалися, а деякі з них навіть купували. Так минуло літо. На початку осені повертається її чоловік Ден. Він переконаний, що молода дружина не здатна оцінити того, який гарний чоловік поряд 3 нею, а тому вона не ставитися до нього належно. Лише пішовши від Мері, він зрозумів, кого втратив. Спочатку Мері радіє поверненню чоловіка. Проте коли вона намагається поділитися 3 ним своїми новими враженнями, він спочатку просить нагодувати його, а потім взагалі не слухає їі. Згодом Ден натякає на те, що йому не до вподоби іiі одяг і нагадує, що вона, як дружина такого Чоловіка, має завжди виглядати гарно. Зрештою Мері повертає на горище свої фарби та пензлі, вдягає «пристойний» одяг і проводить сорок хвилин перед дзеркалом, доки не прокинувся чоловік.

На перший погляд здається, що образ Дена не $є$ головним у цьому оповіданні, однак усі думки та спогади Мері так чи так повертаються до чоловіка. Вона згадує минуле, їхнє подружнє життя і розуміє, що цілком присвятила себе йому, у неї просто не залишилося часу та сил для себе - життя пройшло повз. Проте ії чоловік цього зовсім не цінував: «Вони з Деном тримали там човен. Тоді, два роки тому? Він раптом заявивив, що човен занадто старий i продав його. Це було вперше, коли він зробив щось подібне, не порадивщись з нею. Він розбив ii серие як продажем самого човна, який вона так любила, так і тим, що не порадився з нею. Він не вважав це за потрібне» (пер. наш. - I. Р.) $[2,217]$. Образ Дена можна зарахувати до типу «Син», який вихваляється своєю дорослістю, а потім повертається додому ніби нічого не сталося і продовжує вимагати уваги та жертовності.

Як ми вже зазначали вище, типи представлених образів не $є$ ані поганими, ані гарними. Це добре демонструють наведені приклади. На нашу думку, така двополярність дає змогу письменниці створювати більш детальні та реалістичні чоловічі образи, додати глибини та багатогранності жіночим персонажам. Однак це вже тема для подальшого дослідження.

Таким чином, найулюбленішими маскулінними типами Б. Ерскін $€$ «Джентльмен» та «Романтик»: із 44 оповідань збірки у 16 ми знаходимо перший образ (понад 36 відсотків від загальної кількості творів збірки); і в $11-$ другий (25 відсотків).

На нашу думку, переважна більшість чоловічих образів типу «Джентльмен» може бути пояснена національними та культурними традиціями британського суспільства, описаного в оповіданнях. Однак це зауваження є суб'єктивним припущенням, тому потребує більш глибокого вивчення.

На жаль, наше дослідження обмежене розміром статті й не дає змоги, більш детально презентувати аналіз усіх оповідань, що увійшли у збірку «Несподівані зустрічі». Однак у цій розвідці ми продемонстрували можливий вектор напряму дослідження не тільки сучасної британської, а й української жіночої прози у ракурсі гендерних розвідок.

Перспективи вивчення творчості Барбари Ерскін відкривають можливості розглядати жіночі образи за допомогою літературознавчих методів з урахуванням прийомів гендерних досліджень. Цікавими $є$ також компаративний аналіз сучасної української та англомовної жіночої прози.

\section{ДЖЕРЕЛА}

1. Жаданова Н.И. Мужские образы в современной западной культуре / Н.И. Жаданова // Рубикон. - Ростов-на-Дону, 2005. - Вып. 35. - С. 20-22.

2 Erskine B. Encounters / B. Erskine. - Publ. by Fontana, 1990. - 545 p. 
1. Zhadanova, N. I. (2005). Muzhskie obrazy v sovremennoi zapadnoi kulture. Rostov-na-Donu, Rubikon, Issue 35, pp. 20-22 (in Ukrainian).

2. Erskine, B. (1990). Encounters. Publ. by Fontana, 545 p.

Iryna Rybalka,

$\mathrm{PhD}$ in Philology, docent of the department "Operation of ship power plants» National University «Odessa Maritime Academy»

Mariupol, Ukraine

ORCID iD 0000-0001-6648-7219

iryna190781@ukr.net

\section{MALE IMAGES IN SHORT STORIES BY B. ERSKINE}

The author of the article offers an analysis of male images in the works of the famous British writer B. Erskine's short stories published in the collection of story "Encounters». The analysed fiction texts have not been translated into Ukrainian yet. The study presents the attempt to use the gender research techniques to study literary problems. Using the classification of the male social patterns of behavior worked out by N. Zhadanova, we analyse the collection of stories "Encounters" and single six types of male images: "Knight-aristocrat", "Gentleman", "Mate", "Romantic", "Son", "Father". These types of masculine images are neither positive nor negative, they always combine both traits this adds some more realism. The male image of the type "Gentleman" prevails in the above-mentioned collection, the fact can be explained by the national and cultural traditions of the society, described in the stories. The vector of this study is promising in the multistudy researches, that recently become popular in humanitarian scientific practice.

Key words: gender, type of image. 